\title{
Dietary acid load berhubungan dengan sindrom metabolik dan kesehatan mental pada mahasiswi obesitas
}

The dietary acid load was associated with metabolic syndrome and mental health among obese college students

\author{
Firdananda Fikri Jauharany ${ }^{1}$, Martha Irene Kartasurya ${ }^{2}$, Apoina Kartini², Fillah Fithra Dieny ${ }^{1}$, Dian Ratna
} Sawitri $^{3}$, Etika Ratna Noer ${ }^{1}$

'Departemen Ilmu Gizi, Fakultas Kedokteran, Universitas Diponegoro, Semarang

${ }^{2}$ Departemen Gizi Kesehatan Masyarakat, Fakultas Kesehatan Masyarakat, Universitas Diponegoro, Semarang

${ }^{3}$ Fakultas Psikologi, Universitas Diponegoro, Semarang

\begin{abstract}
Background: The prevalence of metabolic syndrome has been increasing every year in the young population. The western diet is one of the causes that makes excess acid in the body called a dietary acid load. On the other hand, the high dietary acid load was associated with decreased mental health status. Objective: To examine the association between dietary acid load and the risk of metabolic syndrome and mental health. Methods: This was a cross-sectional study conducted with 115 female students in Semarang aged 18-22 years. The dietary acid load was evaluated through the potential renal acid load (PRAL), the risk score for metabolic syndrome was calculated by continuous value of metabolic risk score (cMetS). Mental health status was assessed through levels of self-esteem and levels of anxiety. The level of self-esteem was measured by the Rosenberg self-esteem scale questionnaire, while the level of anxiety was measured by the state anxiety inventory questionnaire. Multiple linear regression models with adjustment for a potential cofounding variable were used to evaluate the association between dietary acid load with metabolic syndrome scores, self-esteem scores, and anxiety scores. Results: The mean PRAL score was $6.11 \pm 9.72 \mathrm{mEq} /$ day indicated the intake of the subjects was a dietary acid load. $13 \%$ of subjects had metabolic syndrome, and $87 \%$ had the pre-metabolic syndrome. 36.5\% of the subjects have low self-esteem scores. The anxiety level score calculation shows that $59.1 \%$ of the subjects are at high risk of anxiety. Pearson test showed that PRAL scores were correlated with anxiety scores $(r=0.69 ;$ $p<0,001)$. The linear regression test showed that PRAL scores were correlated with metabolic syndrome scores $(\beta=0.899 ; p<0.001)$ and self-esteem scores $(\beta=-0.069 ; p=0.047)$. Conclusions: High dietary acid load may be a risk factor related to the development of metabolic disorders and decreased mental health status in females with obesity.
\end{abstract}

KEYWORDS: anxiety; dietary acid load; obesity; metabolic syndrome; self-esteem

\section{ABSTRAK}

Latar belakang: Prevalensi sindrom metabolik meningkat setiap tahun pada populasi muda. Pola makan kebarat-baratan adalah salah satu penyebabnya. Pola ini menyebabkan berlebihnya asam dalam tubuh yang disebut dietary acid load. Di sisi lain, dietary acid load dalam jumlah tinggi juga berkaitan dengan penurunan kondisi kesehatan mental. Tujuan: Penelitian ini bertujuan mengetahui korelasi antara dietary acid load dengan risiko sindrom metabolik dan kesehatan mental. Metode: Penelitian crosssectional pada 115 mahasiswi di Kota Semarang usia 18-22 tahun. Dietary acid load dihitung menggunakan rumus potential renal acid load (PRAL) dan skor risiko sindrom metabolik dihitung menggunakan rumus continuous value of metabolic risk score (cMetS). Status kesehatan mental dikaji melalui tingkat harga diri yang diukur menggunakan kuesioner Rosenberg self-esteem scale sedangkan tingkat kecemasan diukur menggunakan kuesioner state anxiety inventory. Model regresi linier berganda digunakan untuk mengkaji hubungan dietary acid load dengan skor sindrom metabolik, skor tingkat harga diri, dan skor kecemasan. Hasil: Rerata skor PRAL sebesar 6,11 $\pm 9,72 \mathrm{mEq} /$ hari menunjukkan asupan subjek bersifat asam dalam tubuh (dietary acid load). Sebanyak $13 \%$ subjek telah mengalami sindrom metabolik dan $87 \%$ mengalami pra-sindrom metabolik. Sebanyak 36,5\% subjek memiliki skor harga diri yang tergolong rendah dan 59,1\% subjek tergolong cukup cemas. Uji korelasi Pearson menunjukkan korelasi positif yang signifikan antara skor PRAL dengan skor kecemasan $(\mathrm{r}=0,669 ; \mathrm{p}<0,001)$. Setelah variabel perancu dikontrol, model regresi linier berganda menunjukkan skor PRAL berkorelasi dengan skor sindrom metabolik $(\beta=0,899 ; \mathrm{p}<0,001)$ dan skor harga

Korespondensi: Firdananda Fikri Jauharany, Departemen Ilmu Gizi, Fakultas Kedokteran, Universitas Diponegoro, Jl. Profesor Soedharto SH, Tembalang Semarang, Jawa Tengah, Indonesia, e-mail: firdananda22@gmail.com

Cara sitasi: Jauharany FF, Kartasurya MI, Kartini A, Dieny FF, Sawitri DR, Noer ER. Dietary acid load berhubungan dengan sindrom metabolik dan kesehatan mental pada mahasiswi obesitas. Jurnal Gizi Klinik Indonesia. 2021;17(3):113-124. doi: 10.22146/ijcn.59033 
diri $(\beta=-0,069 ; p=0,047)$. Simpulan: Dietary acid load yang tinggi dapat meningkatkan risiko sindrom metabolik dan penurunan kesehatan mental pada perempuan obesitas.

KATA KUNCI: kecemasan; dietary acid load; obesitas; sindrom metabolik; harga diri

\section{PENDAHULUAN}

Peningkatan prevalensi sindrom metabolik secara global telah berkontribusi pada peningkatan morbiditas yang signifikan (1). Keadaan sindrom metabolik meningkatkan risiko lima kali lipat untuk mengalami diabetes mellitus tipe II dan dua kali lipat peningkatan risiko mengalami penyakit jantung (2). Lebih lanjut, keadaan sindrom metabolik juga meningkatkan risiko mengalami stroke 2-4 kali lipat, meningkatkan risiko myocardial infraction 3-4 kali lipat, dan dua kali lipat meningkatkan risiko kematian akibat keadaan tersebut dibandingkan dengan orang tanpa sindrom metabolik (3). Di Indonesia, berdasarkan kriteria Third Report of the National Cholesterol Education Program - Adult Treatment Panel (NCEP-ATP III) dengan modifikasi kriteria untuk Asia, dilaporkan bahwa prevalensi sindrom metabolik pada rentang usia 25-64 tahun di Jakarta sebesar $28,4 \%$ yang terdiri dari $25,4 \%$ pada laki-laki dan $30,4 \%$ pada perempuan (4).

Obesitas merupakan salah satu masalah gizi di negara berkembang dan dikaitkan dengan noncommunicable disease (NCD) seperti non-insulindependent diabetes melitus (NIDDM), penyakit kardiovaskuler, dan kanker. Selain komplikasi medis, obesitas juga dapat menyebakan komplikasi sosial dan emosional. Beberapa penderita obesitas mengeluhkan masalah kecemasan, depresi, dan penarikan diri dari hubungan sosial karena masalah berat badan (5). Keadaan obesitas pada wanita usia 20-24 tahun berkaitan dengan lebih banyak gejala kecemasan dan depresi, tetapi pada pria didapatkan asosiasi yang lemah dan tidak konsisten (6). Di sisi lain, mahasiswa yang tergolong dalam kategori dewasa awal merupakan kelompok rentan mengalami masalah kesehatan mental karena banyak masalah yang dialami ketika masuk usia dewasa seperti harus membuat keputusan mengenai karier, pernikahan, stres terkait pekerjaan dan keluarga, kecemasan, dan depresi.

Asupan berperan utama dalam perkembangan obesitas yang mengakibatkan perkembangan penyakit metabolisme hingga gangguan mental (7). Berfokus pada pola diet daripada makanan tertentu karena pola diet dapat mencerminkan interaksi antara jenis asupan dan kandungan gizinya. Pengukuran dietary acid load (DAL) adalah salah satu formula yang digunakan untuk mengukur beban asam pada makanan (8). Potential renal acid load (PRAL) adalah formula yang memberikan estimasi dietary acid load atau beban asam dari asupan makanan, yaitu asupan protein, kalium, kalsium, magnesium, dan fosfor (9).

Skor DAL yang tinggi mencerminkan konsumsi produk hewani dan makanan olahan yang lebih tinggi dan tidak diimbangi dengan asupan buah dan sayuran. Produk hewani biasanya tinggi protein dan fosfor sehingga bertindak sebagai prekursor asam anorganik potensial yang dapat mempengaruhi produksi asam endogen (9). Jika konsumsi makanan asam tinggi tidak diimbangi dengan peningkatan asupan makanan bersifat basa, dapat menyebabkan asidosis metabolik tingkat ringan hingga kronis (10). Literatur menunjukkan bahwa asidosis metabolik merangsang produksi kortisol, yang memiliki efek merugikan pada faktor risiko terkait sindrom metabolik dan penyakit jantung (11). Skor DAL yang tinggi juga berkaitan dengan peningkatan aktivitas glukokortikoid dan menyebabkan efek yang merugikan terhadap status kesehatan mental (12).

Penelitian mengenai dietary acid load dan kaitannya dengan sindrom metabolik dan kesehatan mental di Indonesia masih terbilang jarang. Penelitian terkait korelasi DAL dan faktor risiko sindrom metabolik menunjukkan hasil yang tidak konsisten $(13,14)$. Penelitian sebelumnya, DAL berkorelasi positif dengan lingkar pinggang (LP) $(14,15)$, kadar trigliserida (15), kolesterol lipoprotein densitas rendah (LDL) (14), dan kolesterol total (14), tetapi berbanding terbalik dengan konsentrasi kolesterol lipoprotein densitas tinggi (HDL) (15). Namun, beberapa penelitian gagal menemukan hubungan antara DAL dan kadar trigliserida, HDL (14), atau gula darah puasa (GDP) $(13,14)$. Selain itu, penelitian yang mengkaji hubungan dietary acid load dengan kesehatan mental baru dilakukan oleh Buhlmeier 
pada kelompok anak-anak dan remaja di Jerman (12). Penelitian terkait asupan gizi seringkali berfokus pada kelebihan atau kekurangan asupan. Penggunaan dietary acid load sebagai indikator aspek gizi dalam penelitian ini akan menggali lebih dalam mengenai efek asupan terhadap status asam basa dalam tubuh dan dampaknya terhadap metabolisme. Di sisi lain, pemilihan mahasiswi sebagai subjek dalam penelitian ini berkaitan dengan usia mahasiswi yang tergolong wanita usia subur (WUS). Keadaan obesitas pada WUS akan berdampak negatif pada masa kehamilan di masa depan akibat gangguan hormon dan metabolisme. Oleh karena itu, perbaikan status gizi sebelum memasuki fase kehamilan perlu dilakukan. Di Indonesia, penelitian yang mengkaji hubungan dietary acid load dengan kesehatan mental pada mahasiswi belum pernah dilakukan. Berdasarkan latar belakang tersebut, penelitian ini bertujuan menganalisis hubungan dietary acid load dengan kejadian sindrom metabolik dan kesehatan mental pada mahasiswi obesitas.

\section{BAHAN DAN METODE}

\section{Desain dan subjek}

Penelitian ini merupakan penelitian deskriptif analitik dengan desain cross-sectional. Penelitian dilaksanakan pada bulan Oktober 2019 - Juni 2020 dengan subjek mahasiswi Universitas Diponegoro, Semarang. Pemilihan sampel dilakukan dengan metode purposive sampling berdasarkan kriteria inklusi yang telah ditentukan. Besar sampel minimal yang diperlukan dihitung menggunakan rumus besar sampel pada

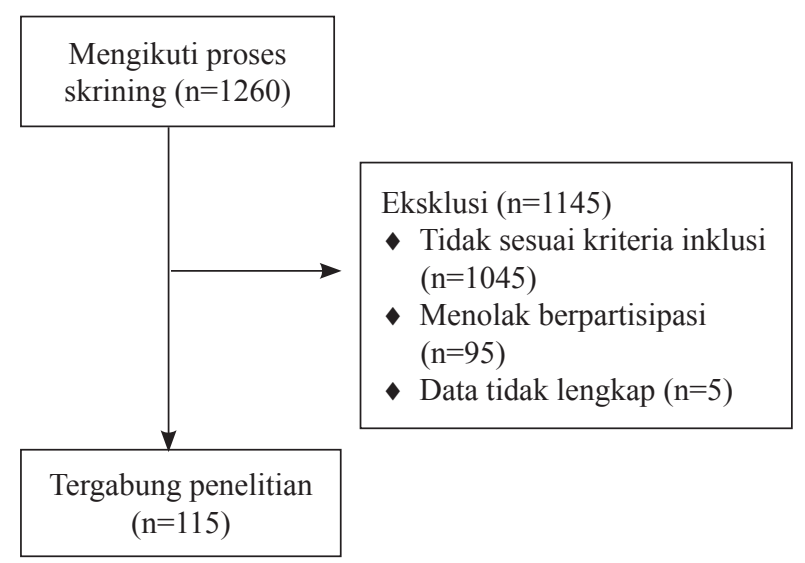

Gambar 1. Alur pemilihan subjek penelitian studi cross-sectional dengan tingkat kemaknaan 95\% $(Z \alpha=1,96)$, kekuatan $90 \%(Z \beta=1,282)$, dan kekuatan korelasi (r) sebesar 0,3 (16) sehingga diperoleh jumlah sampel sebanyak 102 subjek dan untuk menghindari drop out ditambahkan 10\% sehingga jumlah sampel menjadi 113 subjek. Penelitian ini sudah mendapatkan persetujuan etik dari Komisi Etik Penelitian Kesehatan (KEPK) Fakultas Kedokteran Universitas Diponegoro dan mendapatkan surat persetujuan Ethical Clearance dengan nomor 373/EC/KEPK/FK UNDIP/VIII/2019.

Kriteria inklusi subjek dalam penelitian ini adalah mahasiswi Universitas Diponegoro yang memiliki lingkar pinggang lebih dari $80 \mathrm{~cm}$, tidak sedang mengonsumsi obatobatan dan suplementasi diet, tidak sedang menjalankan diet pengurangan jumlah asupan dalam 6 bulan terakhir, belum menikah, dan tidak merokok. Pemilihan subjek penelitian diawali dengan proses skrining dengan mengukur berat badan, tinggi badan, dan lingkar pinggang pada 1.260 mahasiswi, dan didapatkan sebanyak 215 subjek memenuhi kriteria inklusi. Sebanyak 120 subjek bersedia menjadi responden penelitian, namun terdapat 2 subjek yang datanya tidak lengkap sehingga jumlah akhir responden sebanyak 115 subjek (Gambar 1).

\section{Pengumpulan dan pengukuran data}

Dietary acid load. Variabel bebas dalam penelitian ini adalah dietary acid load yang diukur menggunakan rumus PRAL (potential renal acid load). Data asupan diperoleh melalui wawancara kebiasaan konsumsi makanan menggunakan formulir quantitative - food frequency questionnaire (Q-FFQ). Data asupan yang digunakan dalam satuan gram (g) dan dianalisis menggunakan software Nutrisurvey. Skor PRAL dihitung setelah mengetahui asupan harian responden, kemudian dimasukkan ke dalam rumus berikut:

$\operatorname{PRAL}(\mathrm{mEq} /$ hari $)=0,4888 \times$ asupan protein $(\mathrm{g} /$ hari $)+0,0366 \times$ asupan fosfor (mg/hari) $-0,0205 \times$ asupan kalium (mg/hari) - 0,0125 x kalsium (mg/ hari) $-0.0263 \times$ magnesium (mg/hari) (17)

Sindrom metabolik. Keadaan sindrom metabolik diukur menggunakan rumus continuous value of metabolic risk score (cMetS) (18). Skor cMetS dihitung dengan menjumlahkan skor-Z dari lingkar pinggang, mean arterial pressure (MAP), kadar HDL, kadar 
trigliserida, dan kadar gula darah puasa (GDP) (18). Skor cMetS dihitung dengan menjumlahkan skor-Z setiap komponen. Hasil perhitungan skor cMetS yang lebih tinggi menggambarkan tingginya risiko sindrom metabolik. Skor cMetS lebih dari 2,21 dikategorikan berisiko tinggi mengalami sindrom metabolik (19). Pada penelitian ini, keadaan sindrom metabolik juga dikategorikan menurut NCEP-ATP III yang digunakan pada banyak penelitian di Indonesia untuk menilai keadaan sindrom metabolik, jika seseorang memenuhi 3 dari 5 kriteria yang disepakati, yaitu: 1) obesitas sentral (lingkar pinggang wanita $\geq 80 \mathrm{~cm}$ ); 2) tekanan darah sistolik $\geq 130 \mathrm{mmHg}$ atau tekanan darah diastolik $\geq 85 \mathrm{mmHg}$; 3) kadar trigliserida $\geq 150 \mathrm{mg} / \mathrm{dL}$; 4) kadar kolesterol HDL $<50 \mathrm{mg} / \mathrm{dL}$ untuk wanita; 5) kadar glukosa darah puasa $\geq 110 \mathrm{mg} / \mathrm{dL}$ (20).

Kesehatan mental. Data kesehatan mental diukur menggunakan kuesioner Rosenberg self-esteem scale (RSES) untuk mengukur harga diri subjek dan kuesioner state anxiety inventory untuk mengukur tingkat kecemasan $(21,22)$.

Pada penelitian ini, dilakukan pengukuran antropometri, tekanan darah, dan pemeriksaan sampel darah. Pengukuran antropometri yang dilakukan meliputi pengukuran berat badan (BB) menggunakan timbangan injak digital merk TANITA dengan ketelitian 0,01 kg dan pengukuran tinggi badan (TB) menggunakan microtoise dengan ketelitian 0,1 cm. Pengukuran lingkar pinggang (LP) menggunakan metline dengan ketelitian 0,1 cm. Data tekanan darah subjek diukur langsung dengan menggunakan sphygmomanometer air raksa oleh analis kesehatan. Pemeriksaan tekanan darah dilakukan setelah pasien duduk tenang selama 5 menit tidak bergerak maupun berbicara, kaki menempel di lantai, dan posisi lengan disangga setinggi jantung. Tekanan darah diukur 2 kali pada lengan kanan dengan selang waktu 2 menit dan diambil rerata hasil keduanya. Pengambilan sampel darah dilakukan oleh analis laboratorium kesehatan dan bekerja sama dengan Laboratorium Sarana Medika Semarang. Profil darah yang diukur adalah kadar gula darah puasa, kadar trigliserida, dan kadar HDL dengan menggunakan teknik enzymatic colorimetric. Tingkat aktivitas fisik diukur melalui kuesioner International Physical Activity Questionnaire (IPAQ). Skor IPAQ kurang dari $600 \mathrm{MET}$ menit/minggu menunjukkan aktivitas fisik yang tergolong rendah (23).

\section{Analisis data}

Uji normalitas menggunakan KolmogorovSmirnov menunjukkan variabel bebas dan terikat dalam penelitian ini berdistribusi normal. Uji korelasi Pearson digunakan untuk mengetahui korelasi antara dietary acid load dengan sindrom metabolik, skor harga diri, dan skor kecemasan. Model regresi linear berganda dengan penyesuaian untuk variabel perancu digunakan untuk mengevaluasi korelasi dietary acid load dengan skor sindrom metabolik, skor harga diri, dan skor kecemasan. Analisis statistik menggunakan software SPSS versi 22.0 dengan nilai $\mathrm{p}<0,05$ dianggap signifikan.

Tabel 1. Karakteristik subjek penelitian

\begin{tabular}{lrrrrr}
\hline \multicolumn{1}{c}{ Variabel } & Rerata & Median & Simpang baku & Minimal & Maksimal \\
\hline Usia & 19,79 & 20,00 & 0,903 & 18 & 22 \\
Indeks massa tubuh $\left(\mathrm{kg} / \mathrm{m}^{2}\right)$ & 27,40 & 26,69 & 4,42 & 23,13 & 41,82 \\
Lingkar pinggang (cm) & 87,16 & 85,10 & 6,62 & 80,30 & 114 \\
Tekanan darah sistolik (mmHg) & 110,22 & 110,00 & 10,84 & 87 & 144 \\
Tekanan darah diastolik (mmHg) & 76,65 & 76,00 & 7,78 & 57 & 100 \\
Mean arterial blood pressure & 87,75 & 86,67 & 8,03 & 69 & 110 \\
Kadar high density lipoprotein (mg/dL) & 49,67 & 49,00 & 9,51 & 30 & 74 \\
Kadar trigliserida (mg/dL) & 101,75 & 91,00 & 38,15 & 43 & 248 \\
Kadar gula darah puasa (mg/dL) & 87,96 & 87,00 & 68,00 & 68 & 121 \\
Skor cMetS & $-0,24$ & $-0,23$ & 2,29 & $-5,12$ & 5,6 \\
Skor harga diri & 16,09 & 16,00 & 4,61 & 4 & 24 \\
Skor tingkat kecemasan & 50,27 & 51,00 & 5,17 & 40 & 59 \\
Skor tingkat stres & 18,48 & 18,00 & 5,99 & 4 & 32 \\
Skor aktivitas fisik (METmenit/minggu) & 291,87 & 233,00 & 240,51 & 35 & 1.305 \\
\hline
\end{tabular}




\section{HASIL}

Karakteristik subjek dalam penelitian ini meliputi data antropometri, data komponen sindrom metabolik, data skor tingkat kecemasan, harga diri, dan tingkat stress yang ditunjukkan pada Tabel 1. Subjek penelitian berjumlah 115 orang dengan rentang usia 18-22 tahun. Rerata lingkar pinggang subjek dalam penelitian ini

Tabel 2. Kategori karakteristik subjek penelitian

\begin{tabular}{|c|c|c|}
\hline Variabel & $\mathbf{n}$ & $\%$ \\
\hline \multicolumn{3}{|l|}{ Lingkar pinggang } \\
\hline $\operatorname{Normal}(<80 \mathrm{~cm})$ & 0 & 0 \\
\hline Obesitas Sentral $(\geq 80 \mathrm{~cm})$ & 115 & 100 \\
\hline \multicolumn{3}{|l|}{ Tekanan darah sistolik } \\
\hline Normal (<130 mmHg) & 112 & 97,4 \\
\hline Tinggi ( $\geq 130$ mmHg) & 3 & 2,6 \\
\hline \multicolumn{3}{|l|}{ Tekanan darah diastolik } \\
\hline Normal (<85mmHg) & 100 & 87,0 \\
\hline Tinggi ( $\geq 85 \mathrm{mmHg})$. & 15 & 13,0 \\
\hline \multicolumn{3}{|l|}{ Kadar high density lipoprotein } \\
\hline Normal $(\geq 50 \mathrm{mg} / \mathrm{dL})$ & 56 & 48,7 \\
\hline Rendah $(<50 \mathrm{mg} / \mathrm{dL})$ & 59 & 51,3 \\
\hline \multicolumn{3}{|l|}{ Kadar trigliserida } \\
\hline Normal (<150 mg/dL) & 102 & 88,7 \\
\hline Tinggi $(\geq 150 \mathrm{mg} / \mathrm{dL})$ & 13 & 11,3 \\
\hline \multicolumn{3}{|l|}{ Kadar gula darah puasa } \\
\hline Normal (<110 mg/dL) & 113 & 98,3 \\
\hline Tinggi ( $\geq 110$ mg/dL) & 2 & 1,7 \\
\hline \multicolumn{3}{|l|}{ Status sindrom metabolik } \\
\hline Pra-sindrom metabolik (1-2) & 102 & 88,7 \\
\hline Sindrom metabolik $(\geq 3)$ & 13 & 11,3 \\
\hline \multicolumn{3}{|l|}{ cMetS } \\
\hline Normal $(<2,21)$ & 100 & 87,0 \\
\hline Tinggi $(\geq 2,21)$ & 15 & 13,0 \\
\hline \multicolumn{3}{|l|}{ Skor harga diri } \\
\hline Rendah $(<15)$ & 42 & 36,5 \\
\hline Normal $(\geq 15)$ & 73 & 73,0 \\
\hline \multicolumn{3}{|l|}{ Skor tingkat kecemasan } \\
\hline Tidak cemas $(20-35)$ & 0 & 0 \\
\hline Sedikit cemas (36-50) & 47 & 40,9 \\
\hline Cukup cemas (51-65 & 68 & 59,1 \\
\hline Sangat cemas $(66-80)$ & 0 & 0 \\
\hline \multicolumn{3}{|l|}{ Skor tingkat stres } \\
\hline Rendah (0-13) & 23 & 20,0 \\
\hline Sedang (14-26) & 79 & 68,7 \\
\hline Tinggi (27-40) & 13 & 11,3 \\
\hline \multicolumn{3}{|l|}{ Tingkat aktivitas fisik } \\
\hline Ringan $(<600$ METmenit/minggu) & 101 & 87,8 \\
\hline $\begin{array}{l}\text { Sedang (600-3000 METmenit/ } \\
\text { minggu) }\end{array}$ & 14 & 12,2 \\
\hline
\end{tabular}

adalah $87,16 \mathrm{~cm}$, yang menunjukkan bahwa subjek dalam penelitian ini mengalami obesitas. Tekanan darah sistolik dalam penelitian ini memiliki rerata $110,22 \mathrm{mmHg}$ yang menunjukkan bahwa tekanan darah subjek masih tergolong normal.

Nilai normal kadar HDL untuk perempuan adalah $\geq 50 \mathrm{mg} / \mathrm{dL}$, sedangkan dalam penelitian ini hasil pengukuran kadar HDL memiliki rerata 49,67 mg/dL, yang menunjukkan kadar HDL subjek tergolong rendah. Rerata kadar trigliserida dan kadar gula darah puasa dalam penelitian ini masih tergolong normal. Rerata skor cMetS menunjukkan bahwa skor cMetS masih tergolong normal. skor tingkat kecemasan memiliki rerata 50,27 yang menunjukkan kecemasan tingkat rendah, sedangkan rerata skor tingkat stres menunjukkan subjek tergolong stres tingkat sedang. Aktivitas fisik memiliki rerata 291,82 METmenit/minggu yang menunjukkan aktivitas fisik subjek dalam penelitian ini tergolong rendah.

Kategori komponen sindrom metabolik dan skor kesehatan mental ditunjukkan pada Tabel 2. Sebagian besar subjek memiliki skor cMetS yang tergolong normal, hanya $13 \%$ subjek memiliki skor cMetS yang tinggi. Perhitungan skor tingkat kecemasan menunjukkan sebanyak 59,1\% subjek tergolong cukup cemas. Tingkat stres subjek dalam penelitian ini menunjukkan bahwa sebanyak 59,1\% subjek masuk dalam kategori stres tingkat sedang dan sebanyak $11,3 \%$ subjek masuk kategori stres tingkat tinggi.

Tabel 3 menunjukkan karakteristik asupan subjek dalam sehari. Skor PRAL memiliki rerata 6,11 $\mathrm{mEq} / \mathrm{hari}$ yang menunjukkan asupan subjek dalam penelitian cenderung bersifat asam dalam tubuh. Tingkat kecukupan energi mencapai 113,93\%; tingkat kecukupan karbohidrat mencapai $71,81 \%$; tingkat kecukupan protein $16,94 \%$; dan tingkat kecukupan lemak $51,4 \%$ yang menunjukkan bahwa asupan subjek dalam sehari melebihi kebutuhannya. Asupan serat dan sebagian besar mikronutrien dalam penelitian ini tergolong kurang dari kebutuhan, namun untuk rerata asupan vitamin $\mathrm{A}$, fosfor, dan magnesium sudah memenuhi kebutuhan sehari.

\section{Hubungan dietary acid load dengan sindrom metabolik}

Uji korelasi menunjukkan adanya korelasi positif antara dietary acid load dengan skor sindrom metabolik $(\mathrm{r}=0,88 ; p<0,001)$. Selain itu terdapat hubungan yang 
Tabel 3. Asupan gizi subjek dalam sehari

\begin{tabular}{lrrrrr}
\hline \multicolumn{1}{c}{ Variabel } & Rerata & Median & $\begin{array}{r}\text { Simpang } \\
\text { baku }\end{array}$ & Minimal & Maksimal \\
\hline Skor PRAL (mEq/hari) & 6,11 & 4,19 & 9,72 & $-12,33$ & 27,68 \\
Energi (kkal) & $2.280,35$ & $2.237,00$ & 397,88 & $1.420,50$ & $3.235,20$ \\
Karbohidrat (g) & 276,40 & 278,40 & 56,99 & 150,50 & 437,70 \\
Protein (g) & 65,24 & 62,20 & 17,58 & 26,00 & 115,10 \\
Protein hewani (g) & 52,55 & 51,80 & 14,48 & 22,50 & 88,20 \\
Protein nabati (g) & 12,68 & 11,80 & 5,42 & 3,30 & 31,70 \\
Lemak (g) & 87,91 & 85,90 & 19,96 & 46,70 & 137,10 \\
Tingkat kecukupan energi (\%) & 113,93 & 111,09 & 19,87 & 73,24 & 175,34 \\
Tingkat kecukupan karbohidrat (\%) & 71,81 & 72,87 & 14,74 & 39,34 & 109,04 \\
Tingkat kecukupan protein (\%) & 16,94 & 16,47 & 4,47 & 6,74 & 29,01 \\
Tingkat kecukupan lemak (\%) & 51,40 & 49,59 & 11,73 & 28,22 & 82,46 \\
Fosfor (mg) & $1.035,06$ & $1.005,90$ & 244,50 & 531,00 & $1.792,30$ \\
Kalium (mg) & $2.301,81$ & $2.270,60$ & 472,69 & $1.255,40$ & $3.738,20$ \\
Kalsium (mg) & 617,79 & 589,10 & 206,78 & 181,00 & 1234,40 \\
Magnesium (mg) & 318,78 & 318,80 & 108,85 & 53,80 & 644,10 \\
Serat (g) & 10,39 & 8,90 & 5,68 & 2,40 & 28,80 \\
Vitamin A (mcg) & $2.004,99$ & $1.777,80$ & $1.458,19$ & 111,20 & $7.609,20$ \\
Vitamin C (mg) & 48,17 & 45,00 & 28,67 & 3,60 & 210,30 \\
Vitamin E (mg) & 3,04 & 2,30 & 2,90 & 0 & 12,10 \\
Glukosa (g) & 5,31 & 3,80 & 4,38 & 1,20 & 25,20 \\
Fruktosa (g) & 4,79 & 3,10 & 6,14 & 0,50 & 50,00 \\
Galaktosa (g) & 0,22 & 0,10 & 0,33 & 0 & 2,20 \\
Monosakarida (g) & 9,92 & 7,20 & 8,66 & 2,20 & 50,20 \\
Sukrosa (g) & 37,85 & 35,90 & 11,79 & 16,90 & 81,60 \\
Maltosa (g) & 0,21 & 0,20 & 0,16 & 0 & 1,00 \\
Laktosa (g) & 14,16 & 12,70 & 9,72 & 0,10 & 50,30 \\
Disakarida (g) & 52,22 & 51,00 & 17,91 & 19,00 & 112,90 \\
\hline & & & & &
\end{tabular}

signifikan antara asupan energi $(\mathrm{r}=0,278 ; p=0,003)$, maltosa $(\mathrm{r}=0,298 ; p<0,001)$, dan lemak $(\mathrm{r}=0,268$; $p=0,004$ ) terhadap skor sindrom metabolik (Tabel 4).

Analisis bivariat menunjukkan skor PRAL, tingkat kecukupan energi, asupan sukrosa, maltosa, disakarida, tingkat kecukupan karbohidrat, dan tingkat kecukupan lemak memenuhi kriteria untuk masuk dalam model regresi linier berganda. Setelah penyesuaian untuk berbagai variabel perancu (asupan disakarida, sukrosa, maltosa, tingkat konsumsi energi, dan tingkat konsumsi karbohidrat), hubungan positif yang signifikan ditemukan pada skor PRAL $(\beta=0,859 ; \mathrm{p}<0,001)$ dan asupan lemak $(\beta=0,120 ; p=0,008)$ dengan skor sindrom metabolik. Model regresi linier berganda menunjukkan setiap peningkatan $1 \mathrm{mEq}$ skor PRAL dapat meningkatkan skor cMetS sebesar 0,211 (Gambar 2).

\section{Hubungan dietary acid load dengan skor harga diri} dan skor kecemasan

Dalam penelitian ini diketahui tidak ditemukan hubungan yang signifikan antara dietary acid load dengan skor harga diri $(r=-0,139 ; \mathrm{p}=0,138)$. Dietary acid load diketahui memiliki hubungan yang signifikan dengan tingkat kecemasan $(r=0,669 ; p<0,001)$ (Tabel 5).

Dalam penelitian ini juga ditemukan adanya hubungan yang signifikan antara asupan vitamin $\mathrm{C}$ $(\mathrm{r}=-0,248 ; \mathrm{p}=0,008)$ dan skor tingkat stress $(\mathrm{r}=-0,665$; $\mathrm{p}<0,001)$ dengan skor harga diri. Uji korelasi Pearson menunjukkan, skor PRAL, tingkat stres, asupan vitamin $\mathrm{C}$, dan vitamin A memenuhi kriteria untuk masuk dalam model regresi linier berganda. Setelah penyesuaian untuk berbagai variabel perancu, korelasi negatif yang signifikan ditemukan untuk skor PRAL $(\beta=-0,069$; 


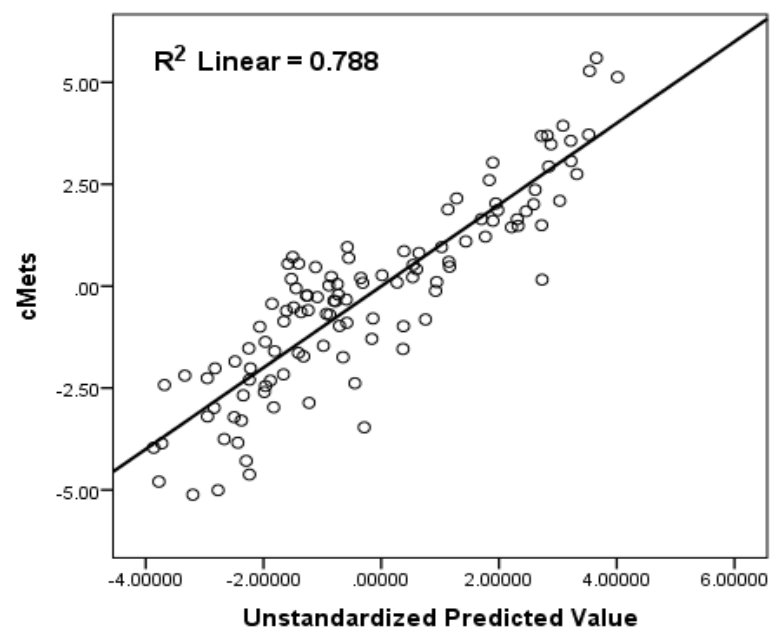

Gambar 2. Model regresi linier berganda skor PRAL dan asupan lemak dengan skor sindrom metabolik

Tabel 4. Hubungan dietary acid load dengan sindrom metabolik

\begin{tabular}{lrr}
\hline \multirow{2}{*}{\multicolumn{1}{c}{ Variabel }} & \multicolumn{2}{c}{ Skor cMetS } \\
\cline { 2 - 3 } & 0,880 & $<0,001^{*}$ \\
\hline Skor PRAL & 0,284 & $0,002^{*}$ \\
Tingkat kecukupan energi & 0,147 & 0,118 \\
Tingkat kecukupan karbohidrat & $-0,076$ & 0,419 \\
Glukosa & 0,024 & 0,798 \\
Fruktosa & 0,001 & 0,994 \\
Galaktosa & $-0,021$ & 0,827 \\
Monosakarida & 0,151 & 0,108 \\
Sukrosa & 0,298 & $<0,001^{*}$ \\
Maltosa & 0,067 & 0,479 \\
Laktosa & 0,138 & 0,141 \\
Disakarida & 0,269 & $0,004^{*}$ \\
Tingkat kecukupan lemak & 0,081 & 0,391 \\
Vitamin A & $-0,057$ & 0,547 \\
Vitamin C & 0,039 & 0,680 \\
Vitamin E & 0,034 & 0,718 \\
Serat & $-0,067$ & 0,479 \\
Aktivitas fisik & 0,018 & 0,845 \\
Tingkat stres & & \\
\hline
\end{tabular}

*signifikan $\mathrm{p}<0,05$

$\mathrm{p}=0,047)$ dan skor tingkat stres $(\beta=-0,512 ; \mathrm{p}<0,001)$. Setiap peningkatan $1 \mathrm{mEq}$ skor PRAL dapat menurunkan skor harga diri sebesar 0,069 (Gambar 3).

\section{BAHASAN}

Skor PRAL memiliki rerata $6,11 \mathrm{mEq} /$ hari. Hal ini menunjukkan pola makan subjek dalam penelitian ini bersifat asam. Berdasarkan hasil wawancara terkait asupan

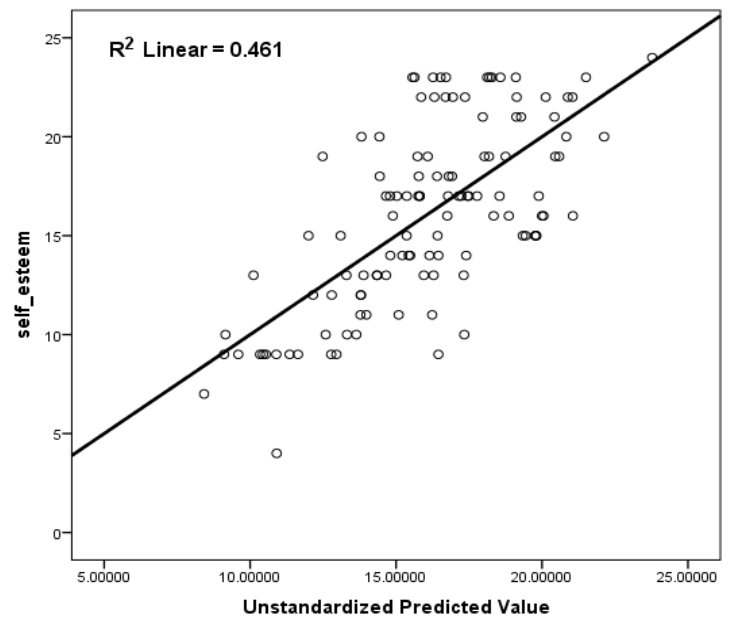

Gambar 3. Model regresi linier berganda skor PRAL dan tingkat stres dengan skor harga diri

Tabel 5. Hubungan dietary acid load dengan skor harga diri dan skor kecemasan

\begin{tabular}{lrrrr}
\hline \multirow{2}{*}{\multicolumn{1}{c}{ Variabel }} & \multicolumn{2}{c}{ Harga diri } & \multicolumn{2}{c}{ Kecemasan } \\
\cline { 2 - 5 } & \multicolumn{1}{c}{$\mathbf{r}$} & $\mathbf{p}$ & \multicolumn{1}{c}{$\mathbf{~}$} & \multicolumn{1}{c}{$\mathbf{p}$} \\
\hline Skor PRAL & $-0,139$ & 0,138 & 0,669 & $<0,001^{*}$ \\
Energi & $-0,053$ & 0,575 & 0,156 & 0,097 \\
Karbohidrat & $-0,097$ & 0,295 & 0,091 & 0,329 \\
Lemak & $-0,041$ & 0,666 & 0,076 & 0,418 \\
Vitamin A & $-0,122$ & 0,195 & 0,071 & 0,452 \\
Vitamin C & $-0,248$ & $\mathbf{0 , 0 0 8}$ & $-0,053$ & 0,572 \\
Vitamin E & 0,017 & 0,856 & $-0,001$ & 0,992 \\
Skor tingkat stres & $-0,665$ & $<\mathbf{0 , 0 0 1}$ & $-0,069$ & 0,463 \\
Aktivitas fisik & $-0,039$ & 0,679 & 0,023 & 0,806 \\
\hline
\end{tabular}

*signifikan $\mathrm{p}<0,05$

makan, diketahui sebagian besar subjek memiliki tingkat konsumsi energi, protein, karbohidrat, dan lemak yang lebih dari kebutuhannya. Sumber protein yang lebih banyak dikonsumsi adalah sumber protein hewani, dengan rerata $52,55 \mathrm{~g}$ /hari, daripada konsumsi protein hewani yang hanya dikonsumsi 12,68 g/hari. Disisi lain, asupan sayur dan buah subjek dalam penelitian ini tergolong kurang. Hal ini dapat dilihat dari rerata asupan serat, yaitu 10,39 g/hari, yang menunjukkan asupan serat kurang dari kebutuhan harian. Pola makan tinggi protein hewani yang bersifat asam dan rendah konsumsi sayur buah yang bersifat basa dalam tubuh, menyebabkan beban asam salam tubuh (dietary acid load).

Hasil penelitian ini menemukan korelasi positif antara dietary acid load dengan sindrom metabolik. Hasil penelitian ini sesuai dengan penelitian sebelumnya yang 
mengkaji dietary acid load dengan sindrom metabolik. Penelitian di Korea Selatan pada kelompok usia 4079 tahun, menemukan peningkatan dietary acid load berkaitan dengan peningkatan risiko sindrom metabolik dan penyakit jantung (24). Penelitian lain yang dilakukan di Iran pada subjek dengan rentang usia 19-70 tahun juga menunjukkan adanya korelasi antara dietary acid load dengan komponen-komponen sindrom metabolik, yaitu lingkar pinggang, kadar trigliserida, kadar HDL, dan tekanan darah diastolik (15).

Hubungan skor PRAL dengan ukuran antropometri berkaitan dengan efek dietary acid load pada metabolisme otot. Studi sebelumnya menunjukkan bahwa asidosis metabolik ringan yang disebabkan oleh acidogenic diet menyebabkan hilangnya jaringan otot melalui penurunan sintesis dan peningkatan proteolisis dan oksidasi asam amino (25). Dietary acid load juga berkontribusi pada perkembangan hipertensi. Asupan yang bersifat lebih asam dapat menyebabkan: 1) peningkatan produksi kortisol yang berpengaruh terhadap vasokonstriksi, 2) peningkatan ekskresi kalsium dan magnesium ginjal, 3) penurunan ekskresi sitrat ginjal, (4) resistensi insulin dan (5) perubahan dalam sekresi hormon insulin-like growth factor-1 (IGF-1) (26). Selain itu, dietary acid load juga berkaitkan dengan peningkatan konsentrasi asam urat karena berkurangnya transportasi urat di tubulus proksimal ke lumen (27), yang dapat menjelaskan efek peningkatan tekanan darah melalui hiperurisemia, yang merupakan faktor risiko independen dari hipertensi (28).

Berdasarkan penelitian meta-analisis yang dilakukan oleh Jayedi et al. pada tahun 2017, diketahui terdapat peningkatan risiko diabetes mellitus tipe 2 sebesar 22\% pada subjek dengan skor PRAL tinggi (RR 1,22, 95\% CI 1,09-1,35, p=0,01) (29). Asidosis metabolik yang diinduksi oleh tingginya dietary acid load menyebabkan terganggunya pengikatan insulin dengan reseptornya, menghambat jalur pengiriman sinyal pada insulin, dan meningkatkan glukoneogenesis hepatik (10). Mekanisme ini menyebabkan pengurangan laju penyerapan glukosa dalam lumen usus, meningkatkan sekresi asam empedu yang dapat menginduksi produksi glucagon-like peptide-1 (30), dan melestarikan komposisi flora usus yang mungkin meningkatkan keadaan resistensi insulin pada subjek (31).
Penelitian yang dilakukan oleh Bahadoran et al. menunjukkan bahwa skor PRAL (rata-rata $=-22 \mathrm{mEq} /$ hari) berkorelasi positif dengan kadar trigliserida dan berbanding terbalik dengan kadar HDL (15). Berbeda dengan penelitian ini, dalam penelitian oleh Murakami et al., skor PRAL secara positif berkorelasi dengan kadar LDL dan kolesterol total pada wanita dewasa muda di Jepang, namun tidak ditemukan korelasi dengan kadar trigliserida (14).

Model regresi linier juga menemukan korelasi positif yang signifikan antara asupan lemak dengan skor sindrom metabolik $(\beta=0,127, p=0,007)$. Berdasarkan wawancara terkait asupan, subjek dalam penelitian ini mengkonsumsi protein hewani yang cukup tinggi dalam sehari dan sebagian besar makanan yang dikonsumsi merupakan makanan yang diolah dengan cara digoreng. Hal ini mungkin turut berkontribusi terhadap peningkatan skor sindrom metabolik pada mahasiswi obesitas. Hasil penelitian ini sama dengan temuan penelitian sebelumnya yang dilakukan di Iran pada subjek berusia 20-74 tahun. Dalam penelitian tersebut, kelompok yang mengkonsumsi asupan lemak berlebih memiliki risiko lebih tinggi mengalami sindrom metabolik (32). Penelitian lain di Spanyol juga menunjukkan adanya korelasi antara tingginya asupan lemak dengan sindrom metabolik (33). Asupan lemak berlebih berkaitan dengan peningkatan lemak viseral pada keadaan obesitas viseral dan mempengaruhi jaringan adiposa untuk mengekspresikan respon terhadap berbagai rangsangan, diantaranya peningkatan pengeluaran asam lemak bebas dan merangsang peningkatan sekresi VLDL di hepar dan menyebabkan peningkatan trigliserida, kadar LDL dan penurunan kadar HDL (34).

Korelasi negatif yang signifikan juga ditemukan antara skor PRAL $(\beta=-0,069, \mathrm{p}=0,047)$ dan tingkat stres $(\beta=-0,512, p=<0,001)$ dengan skor harga diri. Penelitian sebelumnya terkait tingkat harga diri, belum pernah dikorelasikan dengan dietary acid load. Namun penelitian di Spanyol mengaitkan tingkat harga diri dengan diet Mediterania yang bersifat basa dalam metabolisme tubuh. Subjek penelitian ini adalah warga Spanyol ayng menjalankan pola diet Mediterania selama hidupnya. Dalam penelitian tersebut diketahui pola diet Mediterania secara langsung berkaitan dengan tingkat harga diri 
$(\beta=0,37 ; \mathrm{SE}=0,15 ; \mathrm{p}<0,05)$. Diet Mediterania secara signifikan terkait dengan psikologi self-concept $(\beta=0,76$; $\mathrm{SE}=0,28 ; \mathrm{p}<0,01)$. Selanjutnya psikologi self-concept berkaitan dengan harga diri $(\beta=0,20 ; \mathrm{SE}=0,03 ; \mathrm{p}<0,001)$. Hal ini menunjukkan bahwa subjek yang menjalankan pola diet Mediterania cenderung memiliki persepsi yang lebih positif terhadap kesejahteraan fisik, kesejahteraan psikologi, dukungan dan hubungan dengan keluarga dan lingkungannya. Subjek juga menunjukkan harga diri yang lebih positif yang disebabkan pengaruh menjalankan pola diet Mediterania yang bersifat basa dalam tubuh (35).

Keadaan stress berkaitan dengan tingkat harga diri dalam berbagai jalur. Keadaan stress memengaruhi harga diri, dan pada gilirannya harga diri akan memengaruhi cara orang bereaksi terhadap stress dan cara mengatasinya (36). Penelitian yang dilakukan oleh Liu et al. menunjukkan bahwa penilaian harga diri dapat menurun pada usia dewasa (37). Keadaan ini dapat menghilangkan penyeimbang yang biasanya melindungi seseorang terhadap perubahan terkait stress dalam sekresi kortisol. Penurunan harga diri merupakan mekanisme yang berkontribusi pada tingkat sekresi kortisol diurnal yang lebih tinggi dan gangguan axis hypothalamicpituitary-adrenal (HPA).

Skor PRAL juga diketahui memiliki korelasi yang signifikan dengan skor tingkat kecemasan $(\mathrm{r}=0,669$; $\mathrm{p}<0,001)$. Penelitian sebelumnya pada subjek laki-laki dan perempuan dewasa di Iran ditemukan korelasi yang signifikan antara dietary acid load dan kecemasan $(\mathrm{OR}=$ $1,35 ; 95 \% \mathrm{CI}=1,02-1,78$, p-trend $=0,01)(38)$. Sejalan dengan temuan ini, dalam penelitian cross-sectional, pola Western Diet berkaitan dengan peningkatan risiko kecemasan pada 1046 subjek wanita usia 20-93 tahun (39). Studi lain yang dilakukan oleh Weng et al. pada remaja di Jepang menunjukkan bahwa pola diet tinggi produk hewani berkaitan dengan kemungkinan mengalami kecemasan yang tinggi, sedangkan pola diet tradisional (tinggi buah dan sayur) berkaitan dengan penurunan risiko kecemasan (40).

Korelasi positif antara dietary acid load dan gangguan psikologis dapat digambarkan melalui beberapa jalur. Pertama, acid-sensing ion channels la (ASIC1a), yang merupakan saluran $\mathrm{Na}$ degenerin / epitel, yang diaktifkan pada keadaan asidosis. ASICla tereskpresikan dalam system syaraf, khususnya dalam amigdala, yang memainkan peran penting dalam pengaturan suasana hati $(41,42)$. Penelitian sebelumnya pada tikus, menunjukkan ASIC1a yang diekspresikan secara berlebihan akan menimbulkan perasaan takut, sedangkan penghambatan ASIC1a memiliki efek anti-depresi dan anti-kecemasan (43). Oleh karena itu, rendahnya $\mathrm{pH}$ tubuh akibat dietary acid load yang tinggi dapat merangsang ASIC1a dan meningkatkan gangguan psikologis. Kedua, keadaan asidosis metabolik dapat meningkatkan sekresi kortisol (44). Beberapa literatur menunjukkan adanya korelasi positif antara kortisol dan gangguan psikologis $(45,46)$. Ketiga, asdosis metabolik dapat meningkatkan inflamasi (47), sehingga stres oksidatif mungkin mengakibatkan risiko lebih besar mengalami gangguan psikologis (48).

Penelitian ini menunjukkan ketidakseimbangan pola makan mahasiswi yang mengakibatkan risiko tinggi mengalami sindrom metabolik dan penurunan kesehatan mental. Upaya perbaikan pola makan sesuai kebutuhan dan mencakup gizi seimbang perlu dilakukan untuk mencegah keadaan sindrom metabolik dan penurunan kesehatan mental di masa mendatang. Kelemahan penelitian ini adalah desain penelitian cross-sectional sehingga tidak dapat mengetahui hubungan sebab akibat antara dietary acid load dengan sindrom metabolik, harga diri, dan kecemasan. Terlepas dari keterbatasan ini, sejauh pengetahuan kami, ini adalah studi pertama yang menilai hubungan antara dietary acid load dengan sindrom metabolik dan kesehatan mental pada mahasiswi obesitas di Indonesia. Selanjutnya, kelebihan lain dari penelitian ini adalah penggunaan kuesioner QuantitativeFood Frequency Questionnaire (Q-FFQ) yang terlah divalidasi dalam mengevaluasi asupan makanan subjek.

\section{SIMPULAN DAN SARAN}

Korelasi yang signifikan ditemukan antara dietary acid load dengan skor sindrom metabolik, harga diri, dan tingkat kecemasan pada mahasiswi obesitas. Hal ini menunjukkan pola makan subjek obesitas dalam penelitian ini yang bersifat asam berkaitan dengan peningkatan skor sindrom metabolik dan tingkat kecemasan dan berkaitan dengan penurunan skor harga diri. Hasil penelitian ini dapat menjadi salah satu dasar kuat untuk membuat tindakan 
preventif dalam penurunan risiko sindrom metabolik dan penurunan status kesehatan mental, seperti pembuatan kantin sehat yang menyediakan menu-menu berbahan sayur dan buah yang bersifat basa, untuk meningkatkan konsumsi sayur dan buah di kalangan mahasiswa. Mahasiswi obesitas juga perlu diberikan edukasi terkait pengaturan pola makan yang tepat. Pola makan tinggi protein hewani sebaiknya dikurangi dan meningkatkan konsumsi sayur dan buah. Peningkatan asupan sayur dan buah dapat dimulai dengan mengkonsumsi buah potong, jus, dan rujak buah yang banyak dijual di area sekitar kampus.

\section{UCAPAN TERIMA KASIH}

Penelitian ini didanai oleh Hibah Penelitian Dasar Unggulan Perguruan Tinggi Tahun 2019, Kementerian Riset, Teknologi, dan Pendidikan Tinggi.

\section{Pernyataan konflik kepentingan}

Penulis menyatakan tidak ada konflik kepentingan dalam penelitian ini.

\section{RUJUKAN}

1. Roth GA, Johnson C, Abajobir A, Abd-Allah F, Abera SF, Murray C, et al. Global, regional, and national burden of cardiovascular diseases for 10 causes, 1990 to 2015 . J Am Coll Cardiol. 2017;70(1):1-25. doi: 10.1016/j. jacc.2017.04.052

2. Alberti KGMM, Eckel RH, Grundy SM, Zimmet PZ, Cleeman JI, Donato KA, et al. Harmonizing the metabolic syndrome: a joint interim statement of the International Diabetes Federation Task Force on Epidemiology and Prevention; National Heart, Lung, and Blood Institute; American Heart Association; World Heart Federation; International Atherosclerosis Society; and International Association for the Study of Obesity. Circulation. 2009;120(16):1640-5. doi: 10.1161/ CIRCULATIONAHA.109.192644

3. Alberti KGMM, Zimmet P, Shaw J, IDF Epidemiology Task Force Consensus Group. The metabolic syndrome--a new worldwide definition. Lancet. 2005;366(9491):105962. doi: 10.1016/S0140-6736(05)67402-8

4. Soewondo P, Purnamasari D, Oemardi M. Prevalence of metabolic syndrome using NCEP/ATP III criteria in Jakarta, Indonesia: the Jakarta primary non-communicable disease risk factors surveillance 2006. Acta Med Indones. 2010;42(4):199-203.
5. Utami AP, Probosari E, Binar P. Faktor risiko status obesitas terhadap kejadian gangguan psikososial pada remaja putri di Semarang. Media Penelitian dan Pengembangan Kesehatan. 2018;28(1):57-68. doi: 10.22435/mpk. v28i1.7941.57-68

6. Jorm AF, Korten AE, Christensen H, Jacomb PA, Rodgers B, Parslow RA. Association of obesity with anxiety, depression and emotional well-being: a community survey. Aust N Z J Public Health. 2003;27(4):434-40. doi: 10.1111/j.1467-842x.2003.tb00423.x

7. Mental Health Foundation. Food for thought: mental health and nutrition briefing. [series online] 2017 [cited 2020 Jul 27]. Available from: URL: https://www.mentalhealth. org.uk/sites/default/files/food-for-thought-mental-healthnutrition-briefing-march-2017.pdf

8. Scialla JJ, Anderson CAM. Dietary acid load: a novel nutritional target in chronic kidney disease? Adv Chronic Kidney Dis. 2013;20(2):141-9. doi: 10.1053/j. ackd.2012.11.001

9. Remer T, Dimitriou T, Manz F. Dietary potential renal acid load and renal net acid excretion in healthy, free-living children and adolescents. Am J Clin Nutr. 2003;77(5):125560. doi: 10.1093/ajcn/77.5.1255

10. Williams RS, Kozan P, Samocha-Bonet D. The role of dietary acid load and mild metabolic acidosis in insulin resistance in humans. Biochimie. 2016;124:171-7. doi: 10.1016/j.biochi.2015.09.012

11. Fraser R, Ingram MC, Anderson NH, Morrison C, Davies E, Connell JMC. Cortisol effects on body mass, blood pressure, and cholesterol in the general population. Hypertension. 1999;33(6):1364-8. doi: 10.1161/01.hyp.33.6.1364

12. Bühlmeier J, Harris C, Koletzko S, Lehmann I, Bauer C-P, Schikowski T, et al. Dietary acid load and mental health outcomes in children and adolescents: results from the GINIplus and LISA Birth Cohort Studies. Nutrients. 2018;10(5):582. doi: 10.3390/nu10050582

13. Akter S, Eguchi M, Kuwahara K, Kochi T, Ito R, Kurotani $\mathrm{K}$, et al. High dietary acid load is associated with insulin resistance: The Furukawa Nutrition and Health Study. Clin Nutr. 2016;35(2):453-9. doi: 10.1016/j.clnu.2015.03.008

14. Murakami K, Sasaki S, Takahashi Y, Uenishi K, Japan Dietetic Students' Study for Nutrition and Biomarkers Group. Association between dietary acid-base load and cardiometabolic risk factors in young Japanese women. Br J Nutr. 2008;100(3):642-51. doi: 10.1017/ S0007114508901288

15. Bahadoran Z, Mirmiran P, Khosravi H, Azizi F. Associations between dietary acid-base load and cardiometabolic risk factors in adults: The Tehran Lipid and Glucose Study. Endocrinol Metab. 2015;30(2):201-7. doi: 10.3803/ EnM.2015.30.2.201 
16. Jauharany FF, Widyastuti N. Keseimbangan asam-basa tubuh dan kejadian sindrom metabolik pada remaja obesitas. Jurnal Gizi Klinik Indonesia. 2017;14(1):36-44. doi: $10.22146 /$ ijcn. 24811

17. Remer T, Manz F. Potential renal acid load of foods and its influence on urine pH. J Am Diet Assoc. 1995;95(7):791-7. doi: 10.1016/S0002-8223(95)00219-7

18. Shafiee G, Kelishadi R, Heshmat R, Qorbani M, Motlagh ME, Aminaee T, et al. First report on the validity of a continuous metabolic syndrome score as an indicator for metabolic syndrome in a national sample of paediatric population - the CASPIAN-III study. Endokrynol Pol. 2013;64(4):278-84. doi: 10.5603/ep.2013.0006

19. Pratiwi ZA, Hasanbasri M, Huriyati E. Penentuan titik potong skor sindroma metabolik remaja dan penilaian validitas diagnostik parameter antropometri: analisis Riskesdas 2013. Jurnal Gizi Klinik Indonesia. 2017;14(2):80-9. doi: 10.22146/ijcn.25590

20. Grundy SM, Cleeman JI, Daniels SR, Donato KA, Eckel RH, Franklin BA, et al. Diagnosis and management of the metabolic syndrome: an American Heart Association/ National Heart, Lung, and Blood Institute Scientific Statement. Circulation. 2005;112(17):2735-52. doi: 10.1161/CIRCULATIONAHA.105.169404

21. Petersen W. Society and the adolescent self-image. Morris Rosenberg. Science. 1965;148(3671):804. doi: 10.1126/ science.148.3671.804

22. Spielberger C, Gorsuch R, Lushene R, Vagg P, Jacobs G. Manual for the state-trait anxiety inventory (Form Y1 Y2). California: Consulting Psychologists Press; 1983.

23. Forde C. Scoring the international physical activity questionnaire (IPAQ). [series online] 2018 [cited 2020 Jul 27]. Available from: URL: https://ugc.futurelearn. com/uploads/files/bc/c5/bcc53b14-ec1e-4d90-88e31568682f32ae/IPAQ_PDF.pdf

24. Han E, Kim G, Hong N, Lee Y-H, Kim DW, Shin HJ, et al. Association between dietary acid load and the risk of cardiovascular disease: nationwide surveys (KNHANES 2008-2011). Cardiovasc Diabetol. 2016;15(1):122. doi: 10.1186/s12933-016-0436-z

25. Dawson-Hughes B, Harris SS, Ceglia L. Alkaline diets favor lean tissue mass in older adults. Am J Clin Nutr. 2008;87(3):662-5. doi: 10.1093/ajen/87.3.662

26. Osuna-Padilla IA, Leal-Escobar G, Garza-García CA, Rodríguez-Castellanos FE. Dietary acid load: mechanisms and evidence of its health repercussions. Nefrología (English Edition). 2019;39(4):343-54. doi: 10.1016/j. nefro.2018.10.005

27. Esche J, Krupp D, Mensink GB, Remer T. Dietary potential renal acid load is positively associated with serum uric acid and odds of hyperuricemia in the
German adult population. J Nutr. 2018;148(1):49-55. doi: $10.1093 / \mathrm{jn} / \mathrm{nxx} 003$

28. Wang J, Qin T, Chen J, Li Y, Wang L, Huang H, et al. Hyperuricemia and risk of incident hypertension: a systematic review and meta-analysis of observational studies. PLoS ONE. 2014;9(12):e114259. doi: 10.1371/ journal.pone.0114259

29. Jayedi A, Shab-Bidar S. Dietary acid load and risk of type 2 diabetes: a systematic review and dose-response metaanalysis of prospective observational studies. Clin Nutr ESPEN. 2018;23:10-8. doi: 10.1016/j.clnesp.2017.12.005

30. Ma H, Patti ME. Bile acids, obesity, and the metabolic syndrome. Best Pract Res Clin Gastroenterol. 2014;28(4):573-83. doi: 10.1016/j.bpg.2014.07.004

31. Vrieze A, Van Nood E, Holleman F, Salojärvi J, Kootte RS, Bartelsman JFWM, et al. Transfer of intestinal microbiota from lean donors increases insulin sensitivity in individuals with metabolic syndrome. Gastroenterology. 2012;143(4):913-916.e7. doi: 10.1053/j.gastro.2012.06.031

32. Shab-Bidar S, Hosseini-Esfahani F, Mirmiran P, Hosseinpour-Niazi S, Azizi F. Metabolic syndrome profiles, obesity measures and intake of dietary fatty acids in adults: Tehran Lipid and Glucose Study. J Hum Nutr Diet. 2014;27(Suppl 2):98-108. doi: 10.1111/jhn.12117

33. Julibert A, Bibiloni M, Bouzas C, Martínez-González M, Salas-Salvadó J, Corella D, et al. Total and subtypes of dietary fat intake and its association with components of the metabolic syndrome in a Mediterranean population at high cardiovascular risk. Nutrients. 2019;11(7):1493. doi: 10.3390/nu11071493

34. Wang H, Peng D-Q. New insights into the mechanism of low high-density lipoprotein cholesterol in obesity. Lipids Health Dis. 2011;10:176. doi: 10.1186/1476-511X-10-176

35. Knox E, Muros JJ. Association of lifestyle behaviours with self-esteem through health-related quality of life in Spanish adolescents. Eur J Pediatr. 2017;176(5):621-8. doi: 10.1007/s00431-017-2886-Z

36. Galanakis MJ, Palaiologou A, Patsi G, Velegraki I-M, Darviri C. A literature review on the connection between stress and self-esteem. Psychology. 2016;7:687-94. doi: 10.4236/psych.2016.75071

37. Liu SY, Wrosch C, Miller GE, Pruessner JC. Selfesteem change and diurnal cortisol secretion in older adulthood. Psychoneuroendocrinology. 2014;41:111-20. doi: 10.1016/j.psyneuen.2013.12.010

38. Milajerdi A, Keshteli AH, Haghighatdoost F, Azadbakht L, Esmaillzadeh A, Adibi P. Dietary acid load in relation to depression and anxiety in adults. J Hum Nutr Diet. 2020;33(1):48-55. doi: 10.1111/jhn. 12658

39. Jacka FN, Pasco JA, Mykletun A, Williams LJ, Hodge AM, O'Reilly SL, et al. Association of western and 
traditional diets with depression and anxiety in women. Am J Psychiatry. 2010;167(3):305-11. doi: 10.1176/appi. ajp.2009.09060881

40. Weng T-T, Hao J-H, Qian Q-W, Cao H, Fu J-L, Sun Y, et al. Is there any relationship between dietary patterns and depression and anxiety in Chinese adolescents? Public Health Nutr. 2012;15(4):673-82. doi: 10.1017/ S1368980011003077

41. Coryell MW, Ziemann AE, Westmoreland PJ, Haenfler JM, Kurjakovic Z, Zha X, et al. Targeting ASIC1 a reduces innate fear and alters neuronal activity in the fear circuit. Biol Psychiatry. 2007;62(10):1140-8. doi: 10.1016/j. biopsych.2007.05.008

42. Ziemann AE, Allen JE, Dahdaleh NS, Drebot II, Coryell MW, Wunsch AM, et al. The amygdala is a chemosensor that detects carbon dioxide and acidosis to elicit fear behavior. Cell. 2009;139(5):1012-21. doi: 10.1016/j. cell.2009.10.029

43. Wemmie JA, Zha X, Welsh MJ. Acid-sensing ion channels (ASICs) and $\mathrm{pH}$ in synapse physiology. In: Hell JW, Ehlers MD, editors. Structural and functional organization of the synapse. [series online] 2008 [cited $2020 \mathrm{Jul} 27$ ]. Available from: URL: https://doi.org/10.1007/978-0-38777232-5_22
44. Maurer M, Riesen W, Muser J, Hulter HN, Krapf R. Neutralization of western diet inhibits bone resorption independently of $\mathrm{K}$ intake and reduces cortisol secretion in humans. Am J Physiol Renal Physiol. 2003;284(1):F32-40. doi: 10.1152/ajprenal.00212.2002

45. Herane Vives A, De Angel V, Papadopoulos A, Strawbridge $\mathrm{R}$, Wise $\mathrm{T}$, Young AH, et al. The relationship between cortisol, stress and psychiatric illness: new insights using hair analysis. J Psychiatr Res. 2015;70:38-49. doi: 10.1016/j.jpsychires.2015.08.007

46. Zorn JV, Schür RR, Boks MP, Kahn RS, Joëls M, Vinkers $\mathrm{CH}$. Cortisol stress reactivity across psychiatric disorders: a systematic review and meta-analysis. Psychoneuroendocrinology. 2017;77:25-36. doi: 10.1016/j. psyneuen.2016.11.036

47. de Nadai TR, de Nadai MN, Albuquerque AAS, de Carvalho MTM, Celotto AC, Evora PRB. Metabolic acidosis treatment as part of a strategy to curb inflammation. Int J Inflam. 2013;2013:601424. doi: 10.1155/2013/601424

48. Najjar S, Pearlman DM, Alper K, Najjar A, Devinsky O. Neuroinflammation and psychiatric illness. J Neuroinflammation. 2013;10:43. doi: 10.1186/17422094-10-43 